\title{
MENINGKATKAN HASIL BELAJAR SISWA DENGAN MODEL PEMBELAJARAN KOOPERATIF TIPE JIGSAW PADA MATERI JURNAL KHUSUS DIKELAS XII IPS3 SMA NEGERI 1 RANDANGAN \\ (Improving student learning results through with learning models of jigsaw type on jurnal special materials class XII IPS3 SMA Negeri 1 Randangan)
}

\section{La Samula}

Sekolah Menengah Atas Negeri 1 Randangan

Jl. Trans Sulawesi Motolohu, Kecamatan Randangan

Kabupaten Pohuwato, Provinsi Gorontalo, Kode Pos 96268

Email: lasamulafai@gmail.com

\begin{abstract}
ABSTRAK
Tujuan penelitian ini yaitu untuk meningkatkan hasil belajar siswa pada materi Jurnal Khusus dikelas XII IPS3 SMA Negeri 1 Randangan melalui penerapan model Pembelajaran Kooperatif Tipe Jigsaw. Subjek dalam penelitian ini adalah siswa Kelas XII IPS 3 sebanyak 32 orang yang terdiri dari 17 orang Perempuan dan 15 orang laki - laki. Penelitian ini dilaksanakan dalam 2 (dua) siklus, setiap siklus melalui empat tahap. Hasil Penelitian menunjukkan pada Siklus I, dari jumlah 32 siswa terdapat 24 siswa yang tuntas atau $75 \%$ yang memperoleh nilai 75 ke atas dan 8 siswa belum tuntas atau $25 \%$ memperoleh nilai 75 kebawah. Dari hasil tersebut dapat dikategorikan bahwa hasil belajar siswa siklus I belum mencapai ketuntasan sebab pada indikator kinerja yang diharapkan adalah minimal $80 \%$ yang dikenai tindakan memperoleh nilai KKM 75 ke atas. Penelitan Tindakan Kelas pada Siklus II, ditemukan siswa yang tuntas sebanyak 28 siswa atau 87,5\%, yang memperoleh nilai 75 ke atas dan 4 siswa tidak tuntas atau $12,5 \%$, memperoleh nilai 75 ke bawah. Dari hasil tersebut dikategorikan hasil belajar siswa pada siklus II telah mencapai ketuntasan yang diharapakn yakni $80 \%$ siswa yang memperoleh nilai 75 ke atas. meningkatkan Hasil belajar siswa di kelas XII IPS 3 SMA Negeri 1 Randangan.
\end{abstract}

Kata Kunci: Hasil belajar siswa; jurnal khusus; tipe jigsaw;

\begin{abstract}
The purpose of this research was to improve student learning outcomes in the Special Journal material in class XII IPS3 SMA Negeri 1 Randangan through the application of the Jigsaw Type Cooperative Learning model. This study was 32 students of Class XII IPS 3, consisting of 17 women and 15 boys. This research was conducted in 2 (two) cycles, each cycle through four stages. The results showed that in Cycle I, from 32 students, 24 students completed or $75 \%$ who scored 75 and above and 8 students had not completed or $25 \%$ received a 75 and below the score. From these results, it can be categorize that students' learning outcomes in cycle I have not reached completeness because the expected performance indicators are at least $80 \%$ subject to action to obtain a KKM score of 75 and above. In the Classroom Action Research in Cycle II, it found 28 students or $87.5 \%$ of students who completed the score above 75 and 4 students did not complete or $12.5 \%$, got 75 or less. These results categorized student learning outcomes in cycle II have reached the expected completeness, namely $80 \%$ of students who obtained grades 75 and above. Improve student learning outcomes in class XII IPS 3 SMA Negeri 1 Randangan.
\end{abstract}

Keywords: Student learning outcomes; special journal; jigsaw type

\section{PENDAHULUAN}

Di dalam proses belajar mengajar,

guru harus memiliki strategi agar siswa dapat belajar secara efektif dan efisien, mengena pada tujuan yang diharapkan. Salah satu langkah untuk memiliki strategi 
itu ialah harus mengusai teknik - teknik penyajian atau biasanya disebut metode mengajar (Syaifullah, 2012).

Metode mengajar yang guru gunakan dalam setiap kali pertemuan bukanlah asal pakai, tetapi setelah melalui seleksi yang berkesesuain dengan perumusan SK dan KD, sebab dalam kegiatan belajar mengajar bukan semata persoalan menceritakan. Belajar bukanlah konsekuensi otomatis dari perenungan informasi ke dalam benak siswa. Belajar memerlukan kerterlibatan mental dan kerja siswa sendiri. Penjelasan dan pemeragaan semata tidak akan membuahkan hasil yang langgeng. Yang bisa membuahkan hasil belajar yang langgeng hanyalah kegiatan belajar aktif.

Untuk bisa mempelajari sesuatu yang baik, kita perlu mendengar, melihat, mengajukan pertanyaannya dan membahasnya dengan orang lain. Bukan Cuma itu, siswa perlu "mengerjakan" yakni menggambarkan sesuatu dengan cara mereka sendiri, menunjukkan contohnya, mencoba dan memprakteknya.

Dengan menyadari gejala - gejala kenyataan tersebut diatas, maka dalam penelitian ini penulis mengambil Judul Meningkatkan Hasil Belajar Siswa Melalui Penerapan Model Pembelajaran Kooperatif Jigsaw Materi Jurnal Khusus pada Siswa Kelas XII IPS 3 SMA negeri 1 Randangan.

\section{METODE PENELITIAN}

\section{Lokasi Dan Waktu Penelitian}

Penelitian tindakan kelas (PTK) ini dilaksanakan di SMA Negeri 1 Randangan pada Kelas XII IPS 3 dengan Materi Jurnal Khusus dan waktu Pelaksanaan Penelitian pada bulan september 2014. Pelaksanaan Penelitian Tindakan Kelas ini dilaksanakan melalui 4 tahap, yaitu perencanaan (planning), Pelaksanaan Tindakan (action), Pengamatan (pengamatan), dan Refleksi (reflecting) (Arikunto, 2000)

\section{HASIL DAN PEMBAHASAN}

\section{Kegiatan Pembelajaran Siklus I}

Pada siklus I pelaksanaan penelitian mengacu pada prosedur penelitian yang telah ditetapkan terlebih dahulu terlebih dahulu yang meliputi Tahapan persipan, Proses Pelaksanaan Tindakan, dan tahap pengamatan dan evaluasi

\section{Kegiatan Siswa Pada Proses Pembelajaran Siklus I}

Penelitian terhadap kegiatan siswa selama pembelajaran siklus I secara individual selama pembelajaran berlangsung oleh seorang guru mitra, menggunakan pengamatan yang telah disiapkan. Adapun hasil yang dicapai pada pengamatan aktivitas siklus I dapat dilihat pada tabel 3 berikut: 
Tabel 1. Hasil pengamatan aktivitas siswa siklus I

\begin{tabular}{|c|c|c|c|}
\hline No & $\begin{array}{l}\text { Kriteria } \\
\text { Aspek }\end{array}$ & Jumlah & $\begin{array}{l}\text { Presentase } \\
(\%)\end{array}$ \\
\hline 1 & $\begin{array}{l}\text { Sangat } \\
\text { Baik }\end{array}$ & 2 & 25 \\
\hline 2 & Baik & 4 & 50 \\
\hline 3 & Cukup & 2 & 25 \\
\hline 4 & Kurang & 0 & 0 \\
\hline \multicolumn{2}{|c|}{ Jumlah } & 8 & 100 \\
\hline
\end{tabular}

Dari tabel 1 terlihat bahwa dari 8 aspek yang diamati, terdapat 2 aspek atau $25 \%$ yang memperoleh kriteria sangat

Tabel 2. Data hasil belajar siswa siklus I

\begin{tabular}{ccccl}
\hline No & Nilai & Jmlh Siswa & Persentase (\%) & \multicolumn{1}{c}{ Ket } \\
\hline 1 & $60-64$ & 2 & 6.25 & Tidak Tuntas \\
2 & $65-69$ & 2 & 6.25 & Tidak Tuntas \\
3 & $70-74$ & 4 & 12.5 & Tidak Tuntas \\
4 & $75-79$ & 7 & 21.875 & Tuntas \\
5 & $80-84$ & 13 & 40.625 & Tuntas \\
6 & $85-89$ & 2 & 6.25 & Tuntas \\
7 & $90-94$ & 2 & 6.25 & Tuntas \\
8 & $95-100$ & 0 & 0 & - \\
Nilai 75 ke atas & 24 & 75 & Tuntas \\
Nilai 75 ke bawah & 8 & 25 & Tidak Tuntas \\
& Jumlah & 32 & 100 & -
\end{tabular}

\section{Kegiatan Pembelajaran Siklus II}

Seperti halnya pada Siklus I, Siklus II pelaksanaan penelitian mengacu pada prosedur penelitian yang telah ditetapkan terlebih dahulu yang meliputi tahap persiapan, pelaksanaan tindakan, baik, 4 aspek atau 50\% yang memperoleh kriteria baik, dan 2 aspek atau $25 \%$ kriteria cukup.

Dari hasil tabel 2 terlihat bahwa dari 32 siswa yang memperoleh nilai 75 ke atas adalah 24 siswa atau $75 \%$ sedangkan yang memperoleh nilai 75 ke bawah adala 8 siswa atau 25\%. Dari hasil belajar siswa pada siklus I belum mencapai ketuntasan, karena pada indikator ysng diharapkan adalah minimal $80 \%$ siswa yang dikenai tindakan memperoleh nilai 75 ke atas. Dengan demikian penelitian ini perlu lagi dilanjutkan pada siklus berikutnya. pengamatan/pemantauan dan evaluasi, serta analisis dan refleksi.

Kegiatan siswa pada Proses Pembelajaran Siklus II

Kegiatan aktivitas belajar siswa pada proses pembelajaran siklus II ini sama 
seperti siklus I, yakni dilakukan secara individual selama pembelajaran berlangsung oleh guru mitra, menggunakan lembar pengamatan yang telah disiapkan. Adapun hasil yang dicapai pada Siklus II disajikan pada Tabel 6 Berikut ini:
Tabel 3. Hasil pengamatan aktivitas siswa siklus II

\begin{tabular}{cccc}
\hline No & $\begin{array}{c}\text { Kriteria } \\
\text { Aspek }\end{array}$ & Jumlah & $\begin{array}{c}\text { Presentase } \\
(\boldsymbol{\%})\end{array}$ \\
\hline 1 & Sangat Baik & 5 & 62.5 \\
2 & Baik & 2 & 25 \\
3 & Cukup & 1 & 12.5 \\
4 & Kurang & 0 & 0 \\
& Jumlah & $\mathbf{8}$ & $\mathbf{1 0 0}$ \\
\hline
\end{tabular}

Tabel 4. Data hasil belajar siswa siklus II

\begin{tabular}{ccccl}
\hline No & Nilai & Jmlh Siswa & Persentase (\%) & Ket \\
\hline 1 & $60-64$ & 0 & 0 & - \\
2 & $65-69$ & 0 & 0 & - \\
3 & $70-74$ & 4 & 12.5 & Tidak Tuntas \\
4 & $75-79$ & 5 & 15.625 & Tuntas \\
5 & $80-84$ & 7 & 21.875 & Tuntas \\
6 & $85-89$ & 12 & 37.5 & Tuntas \\
7 & $90-94$ & 1 & 3.125 & Tuntas \\
8 & $95-100$ & 3 & 9.375 & Tuntas \\
Nilai 75 ke atas & 24 & 87.5 & Tuntas \\
Nilai 75 ke bawah & 4 & 12.5 & Tidak Tuntas \\
Jumlah & & $\mathbf{3 2}$ & $\mathbf{1 0 0}$ & -
\end{tabular}

Dari tabel 4 tersebut terlihat bahwa dari 32 jumlah siswa yang memperoleh nilai 75 ke atas adalah 28 orang siswa atau $87.5 \%$ sedangkan yang memperoleh nilai 75 ke bawah adalah 4 orang siswa atau 12.5\%. Dari hasil tersebut dapat dikategorikan bahwa kemampuan siswa pada siklus II telah mencapai ketuntasan seperti pada indikator yang diharapkan adalah minimal $80 \%$ siswa yang dikenai tindakan memperoleh nilai 75 ke atas.
Dengan demikian penelitian ini tidak perlu lagi dilanjutkan pada siklus berikutnya.

Dari hasil penelitian pada siklus I dan siklus II menunjukkan bahwa terjadi peningkatan kualitas proses pembelajaran, serta dampaknya terhadap hasil belajar siswa kelas XII IPS 3 SMA Negeri 1 Randangan. Hal ini nampak dari hasil analisis data, baik data yang menyangkut pengamatan kegiatan guru, pengamatan kegiatan siswa, maupun hasil evaluasi 
hasil belajar siswa. Peningkatan kualitas pembelajaran maupun hasil belajar siswa erat kaitannya dengan penggunaan model pembelajaran kooperatif tipe Jigsaw yang diterapkan guru dalam pembelajaran (Isjoni. 2011).

Berdasarkan hasil pengamatan dari kegiatan pembelajaran siklus I, dapat diklasifikasikan siswa tuntas sebanyak 24 orang siswa atau $75 \%$ dan siswa yang belum tuntas sebanyak 8 orang siswa ataun $25 \%$, sehingga dikatakan belum mencapai indikator yang diharapkan yakni minimal Tabel 5. Pengelolaan pembelajaran
$80 \%$ siswa yang dikenai tindakan memperoleh nilai KKM 75 ke atas, sehingga penelitian ini akan dilanjutkan pada siklus II.

Pemberian tindakan siklus II, diperoleh data yang kemudian di analisis seperti pada siklus I. Dari hasil analisis data diketahui terjadi peningkatan hasil belajar siswa yakni siswa yang tuntas sebanyak 28 orang siswa atau $87.5 \%$, dan siswa yang belum tuntas sebanyak 4 orang siswa atau $12.5 \%$.

\begin{tabular}{clcccc}
\hline & & \multicolumn{2}{c}{ Jumlah Aspek } & \multicolumn{2}{c}{ Presentase (\%) } \\
\cline { 3 - 6 } No & Kriteria Aspek & SiklusI & Siklus II & Siklus I & Siklus \\
& & & & & II \\
\hline 1 & Sangat Baik & 1 & 5 & 11.11 & 55.56 \\
2 & Baik & 5 & 3 & 55.56 & 33.33 \\
3 & Cukup & 3 & 1 & 33.33 & 11.11 \\
4 & Kurang & 0 & 0 & 0 & 0 \\
& Jumlah & $\mathbf{8}$ & $\mathbf{8}$ & $\mathbf{1 0 0}$ & $\mathbf{1 0 0}$ \\
\hline
\end{tabular}

Tabel 6. Pengamatan aktivitas siswa

\begin{tabular}{clcccc}
\hline & & \multicolumn{2}{c}{ Jumlah Aspek } & \multicolumn{2}{c}{ Presentase (\%) } \\
\cline { 3 - 6 } No & Kriteria Aspek & Siklus I & Siklus II & Siklus I & Siklus \\
& & & & & II \\
\hline 1 & Sangat Baik & 2 & 5 & 25 & 62.5 \\
2 & Baik & 4 & 2 & 50 & 25 \\
3 & Cukup & 2 & 1 & 25 & 12.5 \\
4 & Kurang & 0 & 0 & 0 & 0 \\
& Jumlah & $\mathbf{8}$ & $\mathbf{8}$ & $\mathbf{1 0 0}$ & $\mathbf{1 0 0}$ \\
\hline
\end{tabular}


Sementara untuk hasil belajar siswa pada materi Jurnal Khusus pada perushaan dagang dengan menggunakan model pembelajaran kooperatif tipe Jigsaw diperoleh gambaran sebagaimana terlihat pada tabel berikut :

Tabel 7. Hasil belajar siswa

\begin{tabular}{cc}
\hline \multirow{2}{*}{ Pembelajaran } & $\begin{array}{c}\text { Peningkatan Hasil } \\
\text { Belajar Siswa }\end{array}$ \\
\cline { 2 - 2 } & Nilai 75 ke atas $(\%)$ \\
\hline Siklus I & 75 \\
Siklus II & 87.5 \\
\hline
\end{tabular}

1. Pada Siklus I; dari jumlah siswa 32 orang siswa, terdapat 24 orang siswa atau $75 \%$ yang memperoleh nilai kriteria tuntas, dan 8 orang siswa lainnya belum tuntas atau $25 \%$

2. Pada Siklus II; sebagai tindak lanjut dan perbaikan dari capaian kualitas pembelajaran siklus I, menunjukkan peningkatan hasil belajar siswa. Dari 32 orang siswa, terdapat 28 orang siswa atau $87.5 \%$ yang tuntas, dan terdapat 4 orang siswa lainnya belum tuntas atau $12.5 \%$

Dengan peningkatan aktivitas guru dan aktivitas siswa, maka akan berdampak positif pada hasil belajar siswa pada materi Jurnal Khusus pada Perusahaan Dagang dalam proses pembelajaran. Hasil pengamatan hasil belajar siswa pada siklus I diperoleh sebesar 75\%, setelah dilaksanakan tindakan siklus II hasil belajar siswa meningkat menjadi $87.5 \%$. Untuk lebih jelasnya peningkatan hasil belajar pada materi Jurnal Khusus pada Perusahaan dagang dapat dilihat pada gambar berikut :

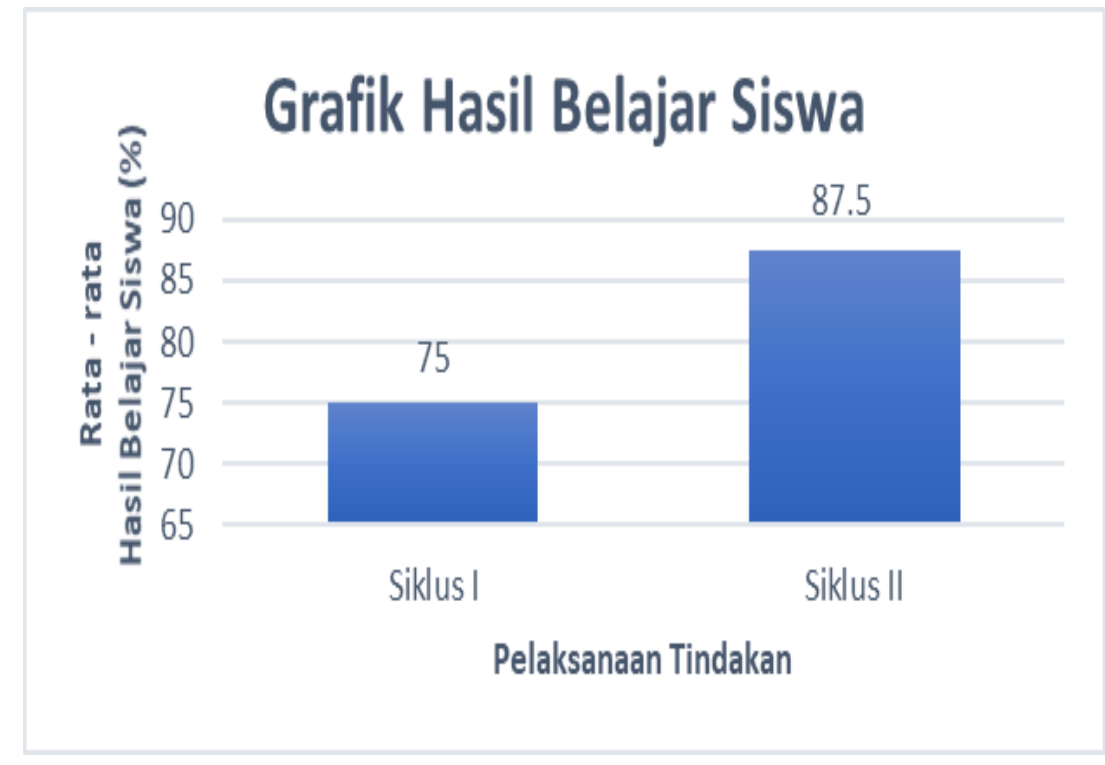

Gambar 1. Peningkatan hasil belajar siswa dari siklus I ke siklus II 
Berdasarkan gambar diatas dapat dijelaskan bahwa hasil capaian pada pelaksanaan siklus I dan Siklus II terjadi peningkatan sebesar $12.5 \%$, sehingga dapat disimpulkan bahwa hasil belajar siswa pada materi Jurnal Khusus pada perusahaan dagang dapat ditingkatkan melalui model pembelajaran kooperatif tipe Jigsaw. Hal ini didukung pula oleh Marleni (2016) yang menyatakan bahwa faktor internal dan eksternal siswa yang menyenangi proses pembelajaran yang dibawa dalam suasana diskusi kelompok. Hal ini menunjukkan bahwa dengan penerapan model pembelajaran koperatif tipe Jigsaw dapat meningkatkan hasil belajar siswa.

\section{KESIMPULAN}

Berdasarkan pelaksanaan penelitian tindkan kelas pada materi Jurnal Khusus pada perusahaan dagang dapat disimpulkan sebagai berikut: Melalui implementasi model Pembelajaran Koperatif tipe Jigsaw, Hasil belajar siswa dalam menyelesaikan soal - soal jurnal Khusus bagi siswa kelas XII IPS 3 SMA Negeri 1 Randangan dapat ditingkatkan. Penelitian tindakan kelas nilai rata - rata pada siklus I adalah 76.56, Siklus II adalah 82.19 dan siswa yang tuntas belajar pada Siklus I adalah 75\%, serta Siklus II adalah $87.5 \%$

\section{DAFTAR PUSTAKA}

Arikunto, S. 2000. Prosedur penelitian. Jakarta: Rineka Cipta

Isjoni, 2011. Cooperative learning (efektivitas pembelajaran kelompok). Bandung: Alfabeta.

Marleni L. 2016. Faktor-faktor yang mempengaruhi minat belajar siswa kelas VIII SMP Negeri 1 Bangkinang. Journal Pendidikan Matematika. 1(1): 149-159.

Syaifullah A.R. 2012 Penerapan model pembelajaran PBI (Problem Based Instruction) dalamupaya peningkatan prestasi belajar siswa kelas X SMK PgriSukodadi Lamongan. Skripsi Program S1 Pendidikan Teknik MesinUniversitas Negeri Surabaya. 